\title{
REDRESSAL OF CONSUMER GRIEVANCES: A CASE STUDY OF STATE CONSUMER DISPUTES REDRESSAL COMMISSION, CHANDIGARH
}

\author{
SUKHDEEP ${ }^{1 *}$ (Research Scholar) AND DR. RAJBANS SINGH GILL ${ }^{2}$ (Associate Professor)
}

\section{*Corresponding Author: -}

\begin{abstract}
: -
Our society has, essentially, been dynamic though its speed of dynamism is found to be varying between that of the bullock-carts to that of the space travel. Man, being a social and rational animal has ever tried to improve upon everything he laid hands on or anything he had invented or discovered.1 His special faculty to thoughtfulness has always been inspiring to channelize all his energies to reach a destination of perfection in life. The inherent virtues of interaction and interdependence of the human beings 2 are taken to be the symbol of dynamism of a civilization. The existing commercialization of every sphere of life gives much more prominence to the most subtle and indispensable interaction between the trader and the consumer.
\end{abstract}

Consumer is all of us and all of us are consumers. Guided, instinctively, by the stomach, 3 we are first the consumers and later the producers. And consumers we remain forever, not merely from cradle to grave, but even beyond these two extremes of our physical existence while producers we remain for a comparatively shorter period of our full life cycle. The simplest sharing of one's surplus produce in

1 Anoop K. Kaushal, (2005), Medical Negligence and Legal Remedies, Universal Law Publishing Co. Pvt. Ltd., Delhi, pp. 2-3. 2 Justice Rama Jois, (2000), Seeds of Modern Public Laws in Ancient Indian Jurisprudence and Human Right, Bhartiya Values, Lucknow, p. 1. 3 A very nice Conclusion of Swami Vivekanand Ji.

exchange for the reciprocated surpluses of different commodities of use, produced by others, was the origin proper of the Barter trade which is as old the society itself.4

Keywords: - Redressal, Consumer, Grievances, Case, Study, State, Consumerdisputes, Redressal Commission, Of, Chandigarh

\section{(c) $\$(1)$}




\section{INTRODUCTION}

Our society has, essentially, been dynamic though its speed of dynamism is found to be varying between that of the bullock-carts to that of the space travel. Man, being a social and rational animal has ever tried to improve upon everything he laid hands on or anything he had invented or discovered. His special faculty to thoughtfulness has always been inspiring to channelize all his energies to reach a destination of perfection in life. The inherent virtues of interaction and interdependence of the human beings are taken to be the symbol of dynamism of a civilization. The existing commercialization of every sphere of life gives much more prominence to the most subtle and indispensable interaction between the trader and the consumer.

Consumer is all of us and all of us are consumers. Guided, instinctively, by the stomach, we are first the consumers and later the producers. And consumers we remain forever, not merely from cradle to grave, but even beyond these two extremes of our physical existence while producers we remain for a comparatively shorter period of our full life cycle. The simplest sharing of one's surplus produce in exchange for the reciprocated surpluses of different commodities of use, produced by others, was the origin proper of the Barter trade which is as old the society itself.

\section{Meaning of Consumer}

According to Collin's School Dictionary, "Consumer is a person who buys goods or uses services." "A consumer is a person or a group of people, such as a household, who are the final user of the products or services. The consumer's use is final in the sense that the product is usually not improved by the use."

Section 2 (1)(d) of the Consumer Protection Act, 1986 defines consumer, " as any person who buys any goods or hires or avail any services for a consideration which has been paid or partially promised, or under any system of deferred payment and includes any user of such goods other than the person who buys such goods for consideration paid or promised or partly paid or partly promised, or under any system of deferred payment, when such use is made with the approval of such person, but does not include a person who obtains such goods for resale or for any commercial purposes.

\section{Need for Consumer Protection}

Ideally speaking, consumers are the wheels of the chariot of economy and they are the kings of the market. But the reality is something very different to these glorious assumptions. Consumers are relegated to a backward position rather than given any commanding supremacy in world. ${ }^{6}$ The plight of the consumer is of a helpless non-entity ignored by the business organisations and neglected by the state. More often so is because he is unorganised and cannot fight against the powerful large-scale organisations. ${ }^{7}$ Hence the marketers have taken the undue advantage of the consumer ignorance and helplessness. They adopt various methods to meet their selfish ends. They have made the consumers the targets of their unscrupulous practices as a result the consumer have become the victim of various types of exploitations such as misuse of colouring matters, short weights, high prices of products, etc.

The need for the consumer protection arises because of the exploitation of the consumers and the denial of the consumer rights in the absence of the protective measures. The widening information gap and the unequal bargaining power between the buyer and the sellers in the market place necessitates measures for consumer protection. Thus, the Consumer protection laws have originated and developed as a natural response to the recognition of the rights of every consumer to be protected against exploitation and abuse by any manufacturer or supplier of goods or service providers.

\section{Consumer Protection in India}

Traced with care, the idea of consumer protection can be found to have existed in every kind of social order and judicial mechanism, whether primitive or modern. However, the extent to which it has been emphasised and sought out to be flourished has varied depending upon the variations in circumstances. The protection of consumers has, therefore been a continues process with different dimensions. But the modern legislation has initiated an era of clear distinction of consumer rights and their protection with a formal system of enforcement.

\section{Before Independence}

Until the advancement of independence there was hardly and legislation enacted primarily to protect consumer interest. Legislative enactments which protected the public interest were the Sale of Goods Act 1930, the Drugs and Cosmetics Act 1940, the Indian Penal Code and some other laws of general applicability.

\section{After Independence}

The first step to protect the consumer interest was taken in 1950 by passing the Drugs Control Act, 1950; followed by Industries (Development and Regulation) Act, 1951, The Indian Standards Institution (Certificate Marks) Act, 1952 (since repealed) and the Drugs and Magic Remedies (Objectionable Advertisements) Act, 1954. But these Acts did not achieve much in view if the urgency felt for science and technology development in the country. It was only in 1954, when a vital step to protect the interest of the consumer was taken, that was passing of Prevention of Food and Adulteration Act, 1954.

\section{The Consumer Protection Act, 1986}

The Consumer Protection Act, 1986 is one of the benevolent social legislation intended to protect the large body of consumers from exploitation. The Act has come as a panacea for consumers all over the country and has assumed the 
shape of practically the important legislation enacted in the country during the last few years. It has become the vehicle for enabling people to secure speedy and in-expensive redressal of their grievances. With the enactment of this law, consumers now feel that they are in a position to declare "sellers be aware" whereas previously the consumers were at the receiving end and generally told "buyers be aware".

The Consumer Protection Act, 1986 is a milestone in the history of socio-legislation in the country. It is one of the most progressive, comprehensive and unique legislation enacted for better protecting the interest of consumers by establishing forums for the settlement of consumer disputes. All the provisions of the consumer protection act, 1986 came in force with effect from 1.7.1987 throughout the country except in the state of Jammu and Kashmir because it has enacted its own legislation in this field. Under the Act, the three tier quasi-judicial consumer dispute redressal machinery was established at the national, state and district levels. These agencies are popularly known as consumer forums or consumer courts.

\section{Organisational Structure of the Consumer Disputes Redressal Agencies in India}

The Consumer Protection Act of 1986 provides for a three-tier Consumer Disputes Redressal system consist of_

a) "District Consumer Disputes Redressal Forum" to be known as District Forum in Each district of every state;

b) "State Consumer Disputes Redressal Commission" to be known as State Commission in every State; and Consumer Courts, assessed on $24^{\text {th }}$ may 2016, from http;//www.chdconsumercourt.gov.in/history.aspx S.S. Chahar (2007), Consumer Protection Movement in India: Problems and Prospects, Kanishka Publishers, Distributors, New Delhi, pp. 13-14.

c) "National Consumer Disputes Redressal Commission" to be known as National Commission.

\section{Scope of the Study}

The present study entitled "Effectiveness of the State Consumer Disputes Redressal Commission, Chandigarh and its Impact" was designed to examine the effectiveness and impact of the State Consumer Disputes Redressal Commission, Chandigarh after analysing the facts. Taking into account the views of the functionaries, consumers and all knowledgeable persons associated with the law of consumer protection. The study was taken to examine the various aspects of the State Consumer Disputes Redressal Commission, Chandigarh stipulated under the Consumer Protection Act, 1986 such as its original structure, procedural aspects, performance and consumers' perceptions. The study also deals with assessing the awareness regarding the consumer protection and the Consumer Protection Act, 1986, amongst the people of Chandigarh.

In 1982, an 'Asian Seminar in Consumer Protection was Organised in schools and colleges, in which 300 delegates from Asian countries participated. Taking this landmark consumer movement into consideration the Prime Minister Indira Gandhi included consumer protection as the $17^{\text {th }}$ programme and it was put on national agenda. For the first time the need to create $t$ a statue for the protection of consumer was felt. The Central Government, during Rajiv Gandhi's tenure as the Prime Minister, presented the bill 'Consumer Protection Act, 1986' to the legislature and was subsequently passed. It came into force on April 15, 1987. By July 1987 all the provisions came into operation. The Consumer Protection Act of 1986 was a milestone in the consumer protection movement in the country. It has been enacted with a view to provide speedy and in-expensive remedy to consumers aims at protecting the consumers from exploitation by traders and service providers.

\section{Structure of the Consumer Disputes Redressal Agencies in India}

In India there is a three tier structure of the Consumer Disputes Agencies. At the National level, there is Central Consumer Protection Council along with National Commission. At the State Level, there is State Consumer Protection Council along with State Commission. At the Present, there are 569 District Forums, 33 State Commissions with Apex body as a National Consumer Disputes Redressal Commission having its office at Janpath Bhavan, New Delhi.

The second in the hierarchy of the Consumer Redressal Forums is the State Commission. The State Commission is required to be established in the each State by the State Government by notification to be published in the Official Gazette. But Chandigarh being a Union Territory comes directly under the Central Rules. As U.T. it has two tiers, Consumer Disputes Redressal mechanism, District Forums and State Commission. State Commission was established on July 1988 and District Forum on June 1988, both at present located at Sector 19, Chandigarh.

\section{Procedure adopted by Consumer Disputes Redressal Agencies}

The Consumer Protection Act, 1986 was enacted to protect the rights of the consumers and to fulfil this objective Consumer Courts were setup for Redressal of grievances. The filing procedure carried out by these Redressal agencies is flexible and has been kept simple so as to facilitate justice.

The procedure for filing the complaint is kept so simple that there is no prescribed performa for the submission of the complaint. However it must be written. It may be submitted directly or by post. A nominal fee is required to be deposited for making complaints before State Commission. A complaint should contain the information like name and address of both the parties, description of the fact of complaint, documentary evidence collaborating the complaint, relief expected and signature of the complainant or his authorised agent.

\section{Performance of the State Consumer Disputes Redressal Commission, Chandigarh}

The study was conducted with the help of Interview Schedule administered to the complainants. For this purpose a sample of 50 (random) complainants out of those whose cases were pending as well as settled with the State 
Commission, Chandigarh was being drawn. A separate Schedule was also prepared to check the consumer awareness among the people of Chandigarh. A sample of another 50 (convenient) consumers, were being drawn to carry out this study.

Table 1.1 gives an account of the performance of the State Commission, Chandigarh. It shows the total number of cases filed/ disposed/ pending at the State Commission, Chandigarh.

Table 1.1: Number of Cases Filed/ Pending/ Disposed of, by the State Commission, Chandigarh

\begin{tabular}{|c|c|c|c|c|}
\hline $\begin{array}{c}\text { Name of the } \\
\text { Agency }\end{array}$ & $\begin{array}{c}\text { Cases filed since } \\
\text { inception }\end{array}$ & $\begin{array}{c}\text { Cases disposed of } \\
\text { since inception }\end{array}$ & Cases pending & $\%$ of total disposal \\
\hline $\begin{array}{c}\text { State Commission } \\
\text { Chandigarh }\end{array}$ & 13994 & 13893 & 101 & $99.28 \%$ \\
\hline
\end{tabular}

Source: Reports of State Commission, Chandigarh

This Table gives an account of the cases filed/ pending/ disposed of, by the State Commission, Chandigarh since its inception as on Dec, 2014. It shows that 99.28 percent of complaints are disposed of by the State Commission, Chandigarh. A total of 13994 complaints were filed at State Commission Chandigarh since its inception out of which 13893 complaints were disposed of and 101 were still pending.

\section{Hiring services of Professionals like Advocates}

The procedure described by the Commission ensures that the courts are consumer friendly and hiring an advocate to present the case is not mandatory. The complainant can present the case on its own in order to get the justice for the wrong done to him by the respondent. Hence, it has been seen that technicalities and formalities forces a complainant to take the help of the professionals.

Reasons for engaging a lawyer were observed as the proceedings are difficult to understand by a layman as it contains legal clauses which requires legal knowledge and a common man is not able to respond or prove these clauses, opposite parties tend to be big organisational firms and they hire experienced professionals to present their case, thus trying to overpower the complainant and to match with these big professionals complainants too have to hire advocates.

Table 1.2: Engaged Lawyer to Present the Case

\begin{tabular}{|c|c|}
\hline Responses of the complainants & Percentage \\
\hline Yes & 94.00 \\
\hline No & 06.00 \\
\hline Total & 100.00 \\
\hline
\end{tabular}

The Table 1.2 shows the responses of the complainants regarding the necessity of lawyer to present the case. Responses shows that $94 \%$ of the complainants have engaged the lawyer to present the case and only $6 \%$ of complainants have not engaged any lawyer. The responses of the complainants showed that most of the complainants have preferred to hire an advocate to argue the case for them and some among those who had not hired the lawyer were planning to engage one due to the problems they were facing in fighting their case.

\section{Awareness among people about State Commission, Chandigarh}

As far as awareness about Consumer Forums in a city like Chandigarh is concerned, we has experienced that people are very well aware of their rights as well as duties and for this reason Chandigarh Consumer Courts have maximum institutions of complaints across the country.

Table 1.3

Responses in Favour of Awareness about Consumer Protection and Redressal Agencies

\begin{tabular}{|c|c|}
\hline Responses of the people & Percentage \\
\hline Education & 40.00 \\
\hline Friends & 34.00 \\
\hline Electronic and Print media & 26.00 \\
\hline Total & 100.00 \\
\hline
\end{tabular}

Responses from the complainants regarding awareness about the Consumer Protection and Redressal Agencies shows that 40 per cent of the people came to know about the consumer protection and Redressal Agencies as part of their Education, 38 per cent were being informed about this by their Friends and 22\% got aware through Electronic and Print media.

Majority of people got aware about the Consumer Protection and Redressal Agencies through their education i.e. they had studied about this at their academic level and many other were made aware by their friends or relatives who had studied about the same at their academic level. This shows that the education system is helping to promote the awareness about these services. Along with this a large portion of city came to know about it through newspapers and advertisements. 
Table 1.4

Reasons for not Going to Consumer Courts

\begin{tabular}{|c|c|}
\hline Reasons & Percentage \\
\hline Legal Hassles & 18.00 \\
\hline Waste of Time & 14.00 \\
\hline Lengthy Procedures & 34.00 \\
\hline Lack of Awareness & 10.00 \\
\hline Never got an opportunity & 24.00 \\
\hline Total & 100.00 \\
\hline
\end{tabular}

Table 1.4 shows the responses given by the respondents when they were asked about the reasons for not filing the case in the Consumer Courts, majority of respondents (34.00\%) cited lengthy procedures followed in the Courts, $24.00 \%$ respondents never got an opportunity to file a case, $18.00 \%$ said that they wanted to avoid the legal hassles, that they did not file the case in the consumer court. $14.00 \%$ respondents said that going to courts is waste of time, $10.00 \%$ expressed lack of awareness about consumer courts.

\section{Conclusion and Suggestions}

Nearly 3 decade after passing of the Consumer Protection Act in December, 1986 clearly brought out a remarkable change in the field of consumer movement. Today's consumers are more aware and conscious of their rights and also know about the protection of their interests. The increasing number of consumer disputes coming to District Forum and State Commission, Chandigarh for Redressal stands as testimony to the dramatic change brought about by the Consumer Protection Act of 1986, in the field of consumer protection. In the much avowed task of consumer protection and Redressal of disputes the role and performance of State Commission, Chandigarh with the disposal rate of $99.28 \%$ is commendable. But still even better protection can be given to the consumer by showing effective advertisement on TV's / Newspapers creating awareness among consumers that filing complaint does not involve any complication and convincing them that they will get justice..

\section{References}

[1].Anoop K. Kaushal, (2005), Medical Negligence and Legal Remedies, Universal Law Publishing Co. Pvt. Ltd., Delhi, pp. 2-3.

[2].Justice Rama Jois, (2000), Seeds of Modern Public Laws in Ancient Indian Jurisprudence and Human Right, Bhartiya Values, Lucknow, p. 1.

[3].A very nice Conclusion of Swami Vivekanand Ji.

[4].R.K. Singh, (1989), Restrictive Trade Practice and Public Interest, Mittal Publication, New Delhi, p. 9.

[5].Bharati Garg, (2013), "Awareness of Consume r Rights in Chandigarh: An Empirical Study" in Research Journal Social Sciences, Vol. 21, No. 2.

[6].Jagbir Singh Narwal and Ranbir Singh Gulia (2007), Consumer Protection: Theory and Practice, in

[7].S.S. Chahar (2007 ) ed., Consumer Protection Movement in India: Problems and Prospects, New Delhi, Kanishka Publishers, Distributers, p. 298.

[8].R.K. Uppal and Rimpi Kaur (2007), Consumer Protection through Mass Awareness : New Challenges and Opportunities, Mahamaya Publishing House, New Delhi, p. 80.

[9].S.K. Verma an M. Afzal Wani (2004), A Treatise on Consumer Protection Laws, Indian Law Institute, New Delhi, p. 1.

[10]. D.N. Saraf (1995), Law of Consumer Protection in India, N.M. Tripathi Pvt. Ltd., Bombay, p. $14-15$.

[11]. Consumer Courts, assessed on $24^{\text {th }}$ may 2016, from http;//www.chdconsumercourt.gov.in/history.aspx

[12]. S.S. Chahar (2007), Consumer Protection Movement in India: Problems and Prospects, Kanishka Publishers, Distributors, New Delhi, pp. 13-14. 